\title{
Jurnal
}

p-ISSN 2621 - 797X ; e-ISSN 2746-6841 DOI:10.32493 Jurnal Disrupsi Bisnis, Vol. 5, No. 1, Januari 2022 (81-91) http://openjournal.unpam.ac.id/index.php/DRB/index

\section{Pengaruh Gaya Kepemimpinan Dan Motivasi Terhadap Kinerja Karyawan Pada PT. Kanmogroup Di Jakarta (Studi Kasus Divisi Fashion Kids Justice)}

\author{
Lili Sularmi ${ }^{1}$, Fauziah Septiani ${ }^{2}$, Suharni Rahayu ${ }^{3}$ \\ 1,2,3 Fakultas Ekonomi dan Bisnis, Universitas Pamulang \\ dosen02042@unpam.ac.id ${ }^{1 *}$ : dosen01771@unpam.ac.id²; dosen00964@unpam.ac.id ${ }^{3}$
}

Received 24 Januari 2022| Revised 24 Januari 2022 | Accepted 31 Januari 2022

*Korespondensi Penulis

\begin{abstract}
Abstrak
Tujuan penelitian ini adalah untuk mengetahui pengaruh variabel gaya kepemimpinan dan motivasi terhadap kinerja karyawan pada PT. Kanmogroup di Jakarta (studi kasus divisi fahion kids justice). Metode yang digunakan dalam penelitian ini adalah kuantitatif dengan pendekatan asosiatif. Populasi dalam penelitian ini adalah seluruh karyawan pada PT. Kanmogroup - Jakarta (studi kasus divisi fahion kids justice) dengan sampel sebanyak 100 responden. Data diambil dengan cara memberikan kuisioner dengan teknik probability sampling dan dianalisis menggunakan uji validitas, uji reliabilitas, uji asumsi klasik, regresi linier berganda, dan koefisien determinasi (R2). Hasil persamaan regresi sederhana $\mathrm{Y}=22,427+0,164 \mathrm{X} 1+0,287 \mathrm{X} 2$. Berarti nilai constanta adalah 22,427 artinya jika tidak terjadi perubahan variable gaya kepemiminan dan motivasi (nilai X1 dan X2) adalah 0 maka kinerja pada karyawan PT. Kanmogroup di Jakarta (studi kasus divisi fashion kids justice) sebesar 22,427 satuan. Tingkat signifikasi pengaruh antara gaya kepemimpinan dan motivasi terhadap kinerja karyawan adalah signifikan. Hal ini dapat dilihat dari nilai Fhitung >Ftabel $(9.136>3,09)$ dengan signifikan $0,000<0,05$ berdasarkan hal tersebut maka Ho ditolak dan Ha diterima.
\end{abstract}

Kata Kunci: Gaya Kepemimpinan;, Motivasi; Kinerja Karyawan

\begin{abstract}
The purpose of this study was to determine the effect of leadership style and motivation variables on employee performance at PT. Kanmogroup in Jakarta (case study of the fashion kids justice division). The method used in this research is quantitative with associative approach. The population in this study were all employees at PT. Kanmogroup - Jakarta (case study of the fashion kids justice division) with a sample of 100 respondents. Data was taken by giving a questionnaire with probability sampling technique and analyzed using validity test, reliability test, classical assumption test, multiple linear regression, and coefficient of determination $(R 2)$. The results of the simple regression equation $Y=22.427+0.164 X 1+0.287 X 2$. It means that the constant value is 22.427 meaning that if there is no change in the leadership style and motivation variable (the values of X1 and X2) are 0 then the performance of the employees of PT. Kanmogroup in Jakarta (case study of the fashion kids justice division) is 22,427 units. The level of significance of the influence between leadership style and motivation on employee performance is significant. This can be seen from the value of Fcount $>$ Ftable $(9.136>3.09)$ with a significance of $0.000<0.05$. Based on this, Ho is rejected and Ha is accepted.
\end{abstract}

Keywords: Leadership Style; Motivation; Employee Performance

\section{PENDAHULUAN}

Dalam suatu manajemen diperlukan Sumber Daya Manusia (SDM) yang berkualitas. Sumber Daya Manusia (SDM) merupakan suatu hal yang sangat penting dan harus dimiliki dalam upaya mencapai tujuan organisasi atau perusahaan. Sumber Daya Manusia (SDM) berperan penting dalam 
suatu perusahaan demi mencapai visi dan misi bagi perusahaan dan untuk mencapai tujuan perusahaan. Dapat didefinisikan bahwa Sumber Daya Manusia (SDM) adalah individu produktif yang bekerja sebagai penggerak suatu organisasi, baik itu di dalam institusi maupun perusahaan yang memiliki fungsi sebagai aset sehingga harus dilatih dan dikembangkan kemampuannya. Seorang pemimpin yang ideal harus memiliki gaya kepemimpinan yang baik yang mampu memotivasi serta memiliki ke pedulian terhadap anggota. Selain itu pemimpin harus mampu menjagakekompakan tim menghargai setiap perbedan dan mempunyai stretegi yang jelas agar dapat meningkatkan kinerja karyawan.

Menurut Rivai (2014:53) Kepemimpinan merupakan suatu faktor yang menentukan tercapai atau tidaknya tujuan suatu instansi, dengan kepemimpinan yang baik, proses manajemen akan berjalan lancar dan pegawai bersemangat melaksanakan tugas-tugasnya.Gaya Kepemimpinan merupakan suatu cara yang dimiliki seorang pemimpin yang menunjukkan suatu sikap yang menjadi ciri khas tertentu untuk mempengaruhi pegawainya dalam mencapai tujuan organisasi (Mulyadi, 2015:150). Pemimpin yang baik akan mampu menyalurkan optimisme dan pengetahuan yang dimiliki agar karyawannya dapat melaksanakan tugas dengan baik. Seorang pemimpin harus memiliki kemampuan memotivasi orang lain untuk melakukan sesuatu sesuai tujuan bersama, dengan kata lain setiap pemimpin harus memperlihatkan contoh yang baik karena karyawan selalu menyorot pemimpinnya. Jika seorang pimpinan tidak biasa memimpin denganbaik, maka akan berpengaruh juga terhadap kinerja karyawan pada perusahan atau instansi tersebut. Jika kinerja karyawan menurun maka tingkat kinerja pada karyawan tersebut juga ikut menurun, maka dari itu gaya kepemimpinan sesorang pemimpin merupakan nilai penting dalam suatu manajemen atau dalam suatu organisasi.

Berikut adalah data penilaian gaya kepemimpinan dari Pimpinan Kantor PT. Kanmogroup Jakarta (studi kasus divisi fashion kids justice)

Tabel 1. Gaya Kepemimpinan

\begin{tabular}{|c|c|c|c|c|}
\hline Indikator & $\begin{array}{c}\text { Penjelasan } \\
\text { Real }\end{array}$ & Real & $\begin{array}{c}\text { Nilai } \\
\text { Karakteristik dan Budaya } \\
\text { Perubahan }\end{array}$ & Keterangan \\
\hline $\begin{array}{l}\text { Pendelegasian } \\
\text { Wewenang }\end{array}$ & $\begin{array}{l}\text { Karyawan ikut } \\
\text { serta medelegasi- } \\
\text { kan wewenang, } \\
\text { kewajiban } \\
\text { serta tanggung } \\
\text { jawab mereka } \\
\text { dalam posisi } \\
\text { jabatanya }\end{array}$ & $\begin{array}{l}\text { Dominan Gaya } \\
\text { Kepemimpinan } \\
\text { Partisipatif }\end{array}$ & $\begin{array}{l}\text { Kantor PT. Kanmogroup } \\
\text { (studi kasus fashion kids } \\
\text { justice) sebuah pe-rusahaan } \\
\text { yang bergerak di bidang } \\
\text { retail perdagangan di } \\
\text { Indonesia }\end{array}$ & $\begin{array}{l}\text { Seharusnya } \\
\text { karyawan tidak } \\
\text { memiliki hak dan } \\
\text { kewajiban dalam } \\
\text { pedelegasian } \\
\text { wewenang. yang } \\
\text { seharusnya } \\
\text { Gaya Kepemiminan } \\
\text { Birokratis }\end{array}$ \\
\hline $\begin{array}{l}\text { Pendiskusian } \\
\text { Masalah }\end{array}$ & $\begin{array}{l}\text { Karyawan } \\
\text { dilibatkan dalam } \\
\text { pendiskusian } \\
\text { masalah yang } \\
\text { terjadi }\end{array}$ & $\begin{array}{l}\text { Dominan Gaya } \\
\text { Kepemimpinan } \\
\text { Partisipatif }\end{array}$ & $\begin{array}{l}\text { Kantor PT. Kanmogroup } \\
\text { (studikasus fashion kids } \\
\text { justice) sebuah perusahaan } \\
\text { yang bergerak di bidang retail } \\
\text { perdagangan di Indonesia }\end{array}$ & $\begin{array}{l}\text { Pimpinan dan kar- } \\
\text { yawan bersama- sama } \\
\text { mendiskusikan } \\
\text { masalah, yang terjadi } \\
\text { di dalam kantor }\end{array}$ \\
\hline \multirow[t]{2}{*}{$\begin{array}{l}\text { Pengambilan } \\
\text { Keputusan }\end{array}$} & $\begin{array}{l}\text { Karyawan diikut } \\
\text { serta melakukan } \\
\text { pengambilan } \\
\text { keputusan dan } \\
\text { kebijaksanaan }\end{array}$ & $\begin{array}{l}\text { Dominan Gaya } \\
\text { Kepemimpinan } \\
\text { Partisipatif }\end{array}$ & $\begin{array}{l}\text { Kantor PT. Kanmogroup (studi } \\
\text { kasus fashion kids justice) } \\
\text { sebuah perusahaan yang } \\
\text { bergerak di bidang retail } \\
\text { perdagangan di } \\
\text { Indonesia }\end{array}$ & $\begin{array}{l}\text { Seharusnya } \\
\text { karyawan tidak } \\
\text { memiliki wewenang } \\
\text { dalam ikut serta } \\
\text { mengambil keputusan } \\
\text { yang seharusnya }\end{array}$ \\
\hline & & & & $\begin{array}{l}\text { dominan Gaya } \\
\text { Kepemimpinan } \\
\text { Birokratis. }\end{array}$ \\
\hline
\end{tabular}




\begin{tabular}{|c|c|c|c|c|}
\hline Indikator & $\begin{array}{c}\text { Penjelasan } \\
\text { Real }\end{array}$ & Real & $\begin{array}{c}\text { Nilai } \\
\text { Karakteristik dan Budaya } \\
\text { Perubahan }\end{array}$ & Keterangan \\
\hline $\begin{array}{l}\text { Pemberian } \\
\text { Toleransi }\end{array}$ & $\begin{array}{l}\text { Pemimpin } \\
\text { memberikan } \\
\text { tegur lisan } \\
\text { kepada karyawan } \\
\text { jika karyawan } \\
\text { melakukan } \\
\text { kesalahan }\end{array}$ & $\begin{array}{l}\text { Dominan Gaya } \\
\text { Kepemimpinan } \\
\text { Partisipatif }\end{array}$ & $\begin{array}{l}\text { Kantor PT. Kanmogroup (studi } \\
\text { kasus fashion kids justice) } \\
\text { sebuah perusahaan } \\
\text { yang bergerak di bidang } \\
\text { retail perdagangan di Indonesia }\end{array}$ & $\begin{array}{l}\text { Pemimpin memberikan } \\
\text { toleransi sesuai } \\
\text { dengan ketentuan } \\
\text { yang berlaku dan } \\
\text { biasa diterima oleh } \\
\text { seluruh karyawan }\end{array}$ \\
\hline $\begin{array}{l}\text { Penerimaan } \\
\text { Saran dan Ide }\end{array}$ & $\begin{array}{l}\text { Karyawan ikut } \\
\text { serta memutuskan } \\
\text { saran dan ide } \\
\text { yang telah } \\
\text { diusulkan }\end{array}$ & $\begin{array}{l}\text { Dominan Gaya } \\
\text { Kepemimpinan } \\
\text { Partisipatif }\end{array}$ & $\begin{array}{l}\text { Kantor PT. Kanmogroup (studi } \\
\text { kasus fashion kids justice) } \\
\text { sebuah perusahaan } \\
\text { yang bergerak di bidang retail } \\
\text { perdagangan di Indonesia }\end{array}$ & $\begin{array}{l}\text { Dalam Penerimaan } \\
\text { saran dan ide, } \\
\text { karyawan berhak } \\
\text { memberikan saran dan } \\
\text { ide }\end{array}$ \\
\hline
\end{tabular}

Sumber: Data Bagian Umum PT. Kanmogroup di Jakarta (studi kasus fashion kids justice)

Menurut beberapa karyawan PT. Kanmogroup di Jakarta (studi kasus fashion kids justice) mengatakan bahwa kurangnya motivasi mempengaruhi semangat bekerja. Selain itu kurangnya motivasi berdampak terhadap rasa tanggung jawab karyawan tersebut terhadap pekerjaannya, oleh karena itu pemimpin harus mampu memotivasi karyawannya.

Menurut Wibowo (2014:3) Kinerja karyawan adalah merupakan implementasi dari rencana yang telah disusun tersebut. Implementasi kinerja dilakukan oleh sumber daya manusia yang memiliki kemampuan, kompetensi, motivasi, dan kepentingan. Menurut Hadari dalam Maulana (2015), mengatakan bahwa kinerja karyawan adalah hasil dari pelaksanaan suatu pekerjaan, baik yang bersifat fisik/mental maupun non fisik/non mental. Kinerja karyawan merupakan satu hal yang sangat penting dalam upaya perusahaan untuk mencapai tujuannya.

Karyawan yang memiliki kinerja yang tinggi, berarti dia memiliki prestasi yang tinggi pula dan berpeluang besar untuk kenaikan karir atau jabatan. Prestasi kerja optimal dan organisasi dapat meningkatkan hasil produksinya secara langsung meningkatkan jumlah produksi yang berpengaruh terhadap kemajuan organisasi.

Tabel 2. Penilaian Kinerja Karyawan PT. KanmoGroup

Jakarta (Studi Kasus Divisi Fashion Kids Justice)

\begin{tabular}{clcccccc}
\hline \multirow{2}{*}{ No } & \multirow{2}{*}{$\begin{array}{l}\text { Indikator } \\
\text { Penilaian }\end{array}$} & \multicolumn{2}{c}{ Tahun 2017} & \multicolumn{2}{c}{ Tahun 2018} & \multicolumn{2}{c}{ Tahun 2019 } \\
\cline { 3 - 8 } & Nilai & Ket & Nilai & Ket & Nilai & Ket \\
\hline 1 & Tujuan & 90 & Sangat Baik & 70 & Cukup & 75 & Cukup \\
\hline 2 & Inisiatif & 82 & Baik & 86 & Baik & 72 & Cukup \\
\hline 3 & Tanggung Jawab & 80 & Baik & 75 & Cukup & 70 & Cukup \\
\hline 4 & Semangat Kerja & 84 & Baik & 72 & Cukup & 73 & Cukup \\
\hline 5 & Hubungan Kemanusiaan & 80 & Baik & 71 & Cukup & 74 & Cukup \\
\hline & Jumlah & 416 & & 374 & & 364 & Cukup \\
\hline
\end{tabular}

Kriteria : 40-50= Buruk ,60-70= Cukup, 80-90 Baik, 90-100 Sangat Baik

Sumber : Data PT. Kanmogroup di Jakarta

\section{Gaya Kepemimpinan}

Gaya Kepemimpinan merupakan suatu cara yang dimiliki seorang pimpinan yang menunjukkan suatu sikap yang menjadi ciri khas tertentu untuk mempengaruhi pegawainya dalam mencapai tujuan organisasi (Mulyadi, 2015:150). Berdasarkan definisi di atas, dapat diketahui bahwa kepemimpinan merupakan kemampuan seorang dalam mengarahkan, mempengaruhi, mendorong dan mengendalikan orang lain atau bawahan untuk bias melakukan sesuatu pekerjaan atas kesadarannya dan sukarela dalam 
mencapai suatu tujuan tertentu. Indikator dari gaya kepemimpinan meliputi: Memiliki strategi yang jelas dan dikomunikasi dengan baik Pemimpin mempunyai strategi yang jelas dan realistis dan anggota percaya terhadap pemimpin dalam melakukan perubahan ke arah yang lebih baik, Kepedulian kepada anggota dan lingkungan memberikan perhatian dan memotivasi kerja anggota dan memperhatikan lingkungan dan kenyamanan bekerja, Merangsang anggota untuk membekali diri dengan pengetahuan dan keahlian dalam usaha meningkatkan kompetensi Menjaga kekompakan tim untuk bekerja dalam timyang solid dan harmonis, Menghargai setiap perbedaan pendapat untuk tujuan lebih baik.

\section{Kinerja Karyawan}

Setiap perusahaan maupun organisasi mengharapkan setiap karyawannya menunjukkan kinerja yang optimal dalam menunjang tercapainya tujuan yang telah ditetapkan sebelumnya. Tanpa didukung oleh kinerja Karyawan yang baik tentunya sebuah organisasi tidak akan maju dan berkembang. Oleh karena itu masalah yang berkaitan dengan kinerja karyawan harus mendapat perhatian pihak manajemen bila hendak mencapai tujuan yang diharapkan. Menurut Wibowo (2017:3) mendefinisikan bahwa kinerja Karyawan adalah merupakan implementasi dari rencana yang telah disusun tersebut. Implementasi kinerja Karyawan dilakukan oleh sumber daya manusia yang memiliki kemampuan, kompetensi, motivasi, dan kepentingan. Edison (2016) kinerja karyawan adalah hasil dari suatu proses yang mengacu dan diukur selama periode waktu tertentu berdasarkan ketentuan atau kesepakatan yang telah ditetapkan sebelumnya. Kinerja Karyawan menjadi cerminan kemampuan dan keterampilannya dalam pekerjaan tertentu yang akan berdampak pada reward dari perusahaan. Indikator nya meliputi: Tujuan, Standar, umpan balik dan alat atau sarana.

\section{Kerangka Pemikiran}

Penelitian ini menggunakan kerangka pemikiran sebagai berikut:

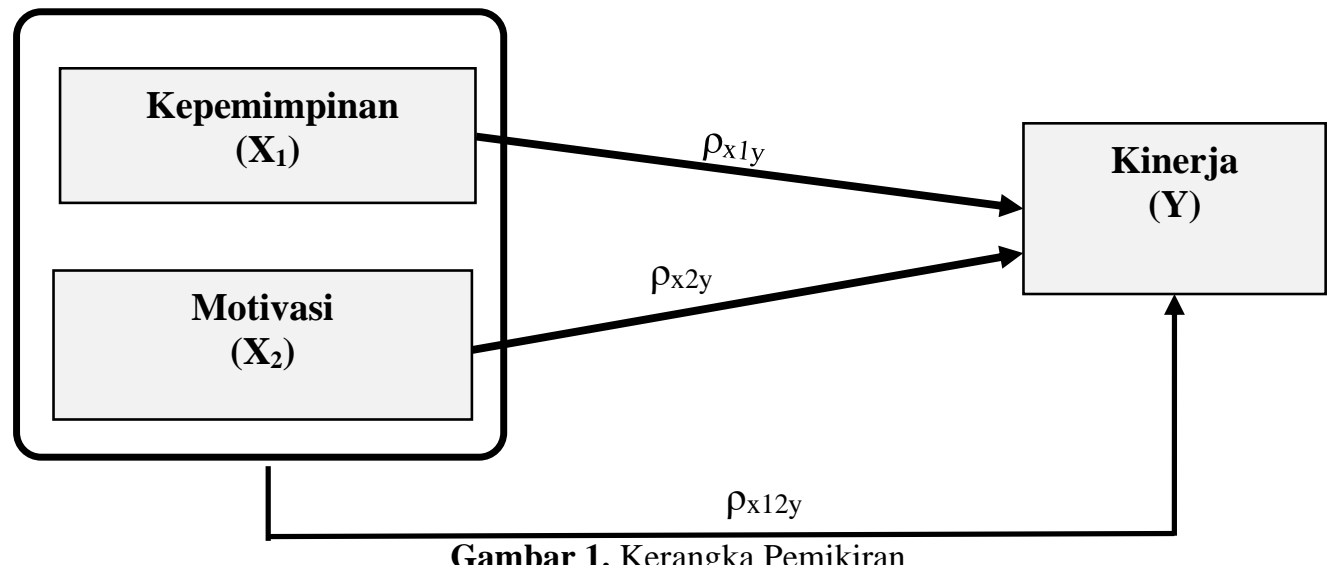

Keterangan:

$\rho_{\mathrm{x} 1 \mathrm{y}}=$ Pengaruh kepemimpinan terhadap kinerja.

$\rho_{\mathrm{x} 2 \mathrm{y}}=$ Pengaruh motivasi terhadap kinerja.

$\rho_{\mathrm{x} 12 \mathrm{y}}=$ Pengaruh kepemimpinan terhadap kinerja.

\section{Hipotesis Penelitian}

Hipotesis dalam penelitian ini:

1. Gaya kepemimpinan $\left(\mathrm{X}_{1}\right)$ berpengaruh signifikan terhadap kinerja karyawan $(\mathrm{Y})$ karyawan pada $\mathrm{PT}$. KANMOGROUP di Jakarta. 
2. Motivasi $\left(\mathrm{X}_{2}\right)$ berpengaruh signifikan terhadap kinerja karyawan $(\mathrm{Y})$ karyawan pada $\mathrm{PT}$. KANMOGROUP di Jakarta.

3. Gaya kepemimpinan $\left(\mathrm{X}_{1}\right)$ dan Motivasi $\left(\mathrm{X}_{2}\right)$ berpengaruh signifikan terhadap kinerja karyawan $(\mathrm{Y})$ karyawan pada PT. KANMOGROUP di Jakarta.

\section{METODE}

Metode yang digunakan dalam penelitian ini yaitu deskriptif kualitatif. Populasi dan sampel seluruh karyawan pada PT. Kanmogroup - Jakarta (studi kasus divisi fahion kids justice) sebanyak 100 responden. Data diambil dengan cara memberikan kuisioner dengan teknik probability sampling dan dianalisis menggunakan uji validitas, uji reliabilitas, uji asumsi klasik, regresi linier berganda, dan koefisien determinasi (R2).

\section{HASIL DAN PEMBAHASAN}

\section{Hasil}

\section{Uji Validitas}

Uji validitas dan reliabilitas variabel gaya kepemimpinan, motivasi dan kinerja karyawan menggunakan bantuan Software IBM SPSS (Statistical Program for Social Science) versi 23 for windows. Seluruh instrument penelitian disiplin kerja dinyatakan valid karena nilai rhitung > rtable.

Tabel 3. Hasil Uji Validitas

\begin{tabular}{|c|c|c|c|c|}
\hline No & Daftar Pernyataan & $\begin{array}{l}\text { Corected Item } \\
\text { Total } \\
\text { Correlation }\end{array}$ & $r_{\text {tabel }}$ & Keterangan \\
\hline \multicolumn{5}{|c|}{ Variabel X1 "Kepemimpinan" } \\
\hline 1 & $\begin{array}{l}\text { Pemimpin memberikan arahan yang jelas tentang } \\
\text { tugas yang diberikan }\end{array}$ & 0.174 & 0.1966 & Valid \\
\hline 2 & $\begin{array}{l}\text { Pemimpin selalu memberikan petunjuk khusus } \\
\text { disetiap tugas yang bersifat kompleks }\end{array}$ & $.361^{* *}$ & 0.1966 & Valid \\
\hline 3 & $\begin{array}{l}\text { Pimpinan saya selalu memberikan motivasi setiap } \\
\text { apel pagi }\end{array}$ & $.300^{* *}$ & 0.1966 & Valid \\
\hline 4 & $\begin{array}{l}\text { Pimpinan menegur anggotanya dengan cara baik- } \\
\text { baik dan memberikan saran dan solusi setiap ada } \\
\text { masalah dalam pekerjaan }\end{array}$ & $.362^{* *}$ & 0.1966 & Valid \\
\hline 5 & $\begin{array}{l}\text { Pimpinan saya selalu memberikan kesempatan } \\
\text { kepada anggotanya untuk belajar dan mengikuti } \\
\text { pelatihan terkait pengamanan }\end{array}$ & $.450^{* *}$ & 0.1966 & Valid \\
\hline 6 & $\begin{array}{l}\text { Pimpinan saya mampu mengarahkan, mendorong } \\
\text { dan mempengaruhi rekan kerja atau bawahanya } \\
\text { untuk bekerja dengan baik }\end{array}$ & 0.096 & 0.1966 & Valid \\
\hline 7 & $\begin{array}{l}\text { Pimpinan saya mengajak anggota membanggun } \\
\text { tim yang solid }\end{array}$ & $.329^{* *}$ & 0.1966 & Valid \\
\hline 8 & $\begin{array}{l}\text { Pimpinan saya membangun suasana kekeluargaan } \\
\text { di dalam organisasi }\end{array}$ & $.629^{* *}$ & 0.1966 & Valid \\
\hline 9 & $\begin{array}{l}\text { Pimpinan saya tidak membeda-bedakan anggota } \\
\text { berdasarkan perbedaan rasa atau pun agama }\end{array}$ & $.358^{* *}$ & 0.1966 & Valid \\
\hline 10 & $\begin{array}{l}\text { Pimpinan saya menghargai setiap pendapat } \\
\text { anggotanya }\end{array}$ & $.452^{* *}$ & 0.1966 & Valid \\
\hline
\end{tabular}

Variabel X2 "Motivasi" 


\begin{tabular}{|c|c|c|c|c|}
\hline No & Daftar Pernyataan & $\begin{array}{l}\text { Corected Item } \\
\text { Total } \\
\text { Correlation }\end{array}$ & $r_{\text {tabel }}$ & Keterangan \\
\hline 1 & $\begin{array}{l}\text { Saya selalu mengerjakan tugas/ pekerjaan saya } \\
\text { dengan standar SOP yang ditetapkan }\end{array}$ & 0.187 & 0.1966 & Valid \\
\hline 2 & $\begin{array}{l}\text { Saya selalu meningkatkan produktifitas kerja saya } \\
\text { untuk mencapai prestasi yang saya inginkan }\end{array}$ & $.361^{* *}$ & 0.1966 & Valid \\
\hline 3 & Saya berkeinginan untuk selalu berkreatifitas & $.302^{* * *}$ & 0.1966 & Valid \\
\hline 4 & $\begin{array}{l}\text { Saya selalu mengerjakan tugas dengan penuh } \\
\text { semangat dan percaya diri }\end{array}$ & $.359^{* *}$ & 0.1966 & Valid \\
\hline 5 & $\begin{array}{l}\text { Saya memiliki inisiatif yang berguna membantu } \\
\text { penyelesaian pekerjaan yang lebih baik }\end{array}$ & $.447^{* *}$ & 0.1966 & Valid \\
\hline 6 & $\begin{array}{l}\text { Saya melaksanakan beban kerja tanpa harus } \\
\text { dibantu karyawan lain }\end{array}$ & 0.097 & 0.1966 & Valid \\
\hline 7 & $\begin{array}{l}\text { Saya melakukan perbaikan atas pekerjaan yang } \\
\text { salah }\end{array}$ & $.332^{* *}$ & 0.1966 & Valid \\
\hline 8 & Saya memiliki perencanaan kerja & $.625^{* *}$ & 0.1966 & Valid \\
\hline 9 & $\begin{array}{l}\text { Saya selalu membantu rekan kerja bila teman kerja } \\
\text { saya merasa kesulitan dan pekerjaanya }\end{array}$ & $.357^{* *}$ & 0.1966 & Valid \\
\hline 10 & $\begin{array}{l}\text { Saya mampu berkomunikasi dan menjalin } \\
\text { hubungan baik dengan rekan kerja }\end{array}$ & $.454^{* *}$ & 0.1966 & Valid \\
\hline \multicolumn{5}{|c|}{ Variabel Y " Kinerja Karyawan" } \\
\hline 1 & $\begin{array}{l}\text { Menurut saya perusahaan dapat mensejahterakan } \\
\text { karyawannya sesuai dengan visi dan misi } \\
\text { perusahaan }\end{array}$ & $.287^{* *}$ & 0.1966 & Valid \\
\hline 2 & $\begin{array}{l}\text { Saya sudah melakukan pekerjaan sesuai standar } \\
\text { SOP perusahaan }\end{array}$ & $.488^{* *}$ & 0.1966 & Valid \\
\hline 3 & $\begin{array}{l}\text { Setau saya perusahaan tempat saya bekerja } \\
\text { memiliki standart yang baik dalam urusan } \\
\text { pelayanan terhadap konsumen }\end{array}$ & $.696^{* *}$ & 0.1966 & Valid \\
\hline 4 & $\begin{array}{l}\text { Membebaskan karyawan dalam berpendapat } \\
\text { adalah kelebihan perusahaan tempat saya bekerja }\end{array}$ & $.543^{* *}$ & 0.1966 & Valid \\
\hline 5 & $\begin{array}{l}\text { Alat dan sarana untuk bekerja sangat diperhatikan } \\
\text { oleh perusahaan saya mulai dari transport, } \\
\text { laPT.op, bahkan mendapatkan uang makan }\end{array}$ & $.383^{* *}$ & 0.1966 & Valid \\
\hline 6 & Saya memberikan masukan saat dimintai pendapat & $.237^{*}$ & 0.1966 & Valid \\
\hline 7 & $\begin{array}{l}\text { Saya mengarahkan rekan kerja sesuai dengan } \\
\text { perintah pimpinan }\end{array}$ & 0.081 & 0.1966 & Valid \\
\hline 8 & Saya bekerja keras dalam memenuhi kebutuhan. & $.623^{* *}$ & 0.1966 & Valid \\
\hline 9 & $\begin{array}{l}\text { Saya bekerja keras agar karir dan kontrak kerja } \\
\text { saya diperpanjang }\end{array}$ & $.630^{* *}$ & 0.1966 & Valid \\
\hline 10 & Saya memiliki jenjang karir ditempat saya bekerja & $.217^{*}$ & 0.1966 & Valid \\
\hline
\end{tabular}




\section{Uji Reliabilitas Kinerja}

Uji validitas dan reliabilitas variabel kinerja menggunakan bantuan Software IBM SPSS (Statistical Program for Social Science) versi 23 for windows. Seluruh instrument penelitian kinerja dinyatakan reliabel apabila nilai Cronbach Alpha > 0,6.

Tabel 4. Hasil Uji Reliabilitas X1,X2 dan Y

\begin{tabular}{cccc}
\hline \multicolumn{4}{c}{ Reliability Statistics (X1) } \\
Cronbach's Alpha & Nof Items & Nilai kritis & Keputusan \\
\hline 0.211 & 10 & 0,60 & Reliabel \\
\hline \multicolumn{4}{c}{ Reliability Statistics $\mathbf{( X 2 )}$} \\
\hline Cronbach's Alpha & Nof Items & Nilai kritis & Keputusan \\
\hline 0.216 & 10 & 0,60 & Reliabel \\
\hline \multicolumn{4}{c}{ Reliability Statistics (Y) } \\
\hline Cronbach's Alpha & Nof Items & Nilai kritis & Keputusan \\
\hline 0.475 & 10 & 0,60 & Reliabel \\
\hline
\end{tabular}

\section{Analisis Regresi Berganda}

Kegunaan regresi linier berganda dalam penelitian salah satunya adalah untuk meramalkan variabel terikat $(\mathrm{Y})$ apabila variabel bebas $(\mathrm{X} 1, \mathrm{X} 2$ diketahui. Adapun rumus yang digunakan adalah sebagai berikut:

Tabel 5. Uji Analisis Regresi Linier Berganda

\begin{tabular}{|c|c|c|c|c|c|c|}
\hline \multicolumn{7}{|c|}{ Coefficients ${ }^{a}$} \\
\hline & \multirow[t]{2}{*}{ Model } & \multicolumn{2}{|c|}{$\begin{array}{c}\text { Unstandardized } \\
\text { Coefficients }\end{array}$} & \multirow{2}{*}{$\begin{array}{c}\text { Standardized } \\
\text { Coefficients }\end{array}$} & \multirow[t]{2}{*}{$t$} & \multirow[t]{2}{*}{ Sig. } \\
\hline & & $B$ & Std. Error & & & \\
\hline \multirow[t]{3}{*}{1} & (Constant) & 22,427 & 5,616 & & 3,993 &, 000 \\
\hline & X1_Gaya Kepemimpinan &, 164 & ,091 & , 169 & 1,804 &, 074 \\
\hline & X2_Motivasi & ,287 &, 124 & ,216 & 2,310 &, 023 \\
\hline
\end{tabular}

a. Dependent Variable: $Y_{-}$Kinerja Karyawan

Sumber : data diolah

Berdasarkan hasil perhitungan tersebut diatas maka dapat diperoleh persamaan regresi linier berganda sebagai berikut: $Y=\mathbf{2 2}, \mathbf{4 2 7}+\mathbf{0 , 1 6 4 X}+\mathbf{0 , 2 8 7} \mathbf{X}_{2}$

\section{Analisis Koefisien korelasi}

Analisis koefisien korelasi dimaksudkan untuk mengetahui bagaimana tingkat hubungan antara variabel independen dengan variabel dependen. Menurut Sugiyono (2014:274), persamaan korelasi pearson dinyatakan dalam rumus :

Tabel 6. Hasil Uji Analisis Koefisien Korelasi

\begin{tabular}{llccc}
\hline \multicolumn{4}{c}{ Correlations } \\
\hline & \multicolumn{1}{c}{$\begin{array}{c}\text { X1_Gaya } \\
\text { Kepemimpinan }\end{array}$} & $\begin{array}{c}\text { X2_ } \\
\text { Motivasi }\end{array}$ & $\begin{array}{c}\text { Y_Kinerja } \\
\text { Karyawan }\end{array}$ \\
\hline \multirow{2}{*}{$\begin{array}{l}\text { X1_Gaya } \\
\text { Kepemimpinan }\end{array}$} & Pearson Correlation & 1 &, $260^{* *}$ &, $326^{* *}$ \\
\cline { 2 - 5 } & Sig. (2-tailed) & 100 &, 009 &, 001 \\
\cline { 2 - 5 } & $N$ &, $260^{* *}$ & 100 & 100 \\
\hline X2_Motivasi & Pearson Correlation &, 009 & 100 &, $311^{* *}$ \\
\cline { 2 - 5 } & Sig. (2-tailed) & 100 & 1002 \\
\cline { 2 - 5 } & Pearson Correlation &, $326^{* *}$ &, $311^{* *}$ & 1 \\
\hline
\end{tabular}




\begin{tabular}{lrrrr}
\hline Y_Kinerja & Sig. (2-tailed) &, 001 &, 002 & \\
\cline { 2 - 5 } Karyawan & $N$ & 100 & 100 & 100 \\
\hline **. Correlation is significant at the 0.01 level (2-tailed). & & \\
\hline
\end{tabular}

Sumber : data diolah

\section{Analisis Koefisien Determinasi}

Nilai koefisien determinasi adalah nol dan satu. Nilai $\mathrm{R}^{2}$ yang kecil berarti kemampuan variabelvariabel independen dalam menjelaskan variabel dependen sangat terbatas. Sebaliknya, nilai $\mathrm{R}^{2}$ yang mendekati satu berarti variabel-variabel independen memberikan hampir semua informasi yang dibutuhkan untuk memprediksi variasi variabel dependen.

Tabel 7. Hasil Uji Analisis Koefisien Determinasi X1 dan Y

\begin{tabular}{rcccc}
\hline \multicolumn{4}{c}{ Model Summary } \\
Model & $R$ & $R$ Square & Adjusted $R$ Square & Std. Error of the Estimate \\
\hline 1 &, $171^{\mathrm{a}}$ &, 029 &, 023 & 3,172 \\
\hline
\end{tabular}

a. Predictors: (Constant), X1_Gaya Kepemimpinan

Sumber : data diolah

Tabel 8. Hasil Uji Analisis Koefisien Determinasi X2 dan Y

\begin{tabular}{|c|c|c|c|c|}
\hline \multicolumn{5}{|c|}{ Model Summary } \\
\hline Model & $R$ & $R$ Square & Adjusted R Square & Std. Error of the Estimate \\
\hline 1 &, $311^{\mathrm{a}}$ & ,096 & ,087 & 3,087 \\
\hline \multicolumn{5}{|c|}{ a. Predictors: (Constant), X1_Motivasi } \\
\hline
\end{tabular}

Tabel 9. Hasil Uji Analisis Koefisien Determinasi

\begin{tabular}{ccccc}
\multicolumn{4}{c}{ Model Summary } \\
\hline Model & $R$ & $R$ Square & Adjusted $R$ Square & Std. Error of the Estimate \\
\hline 1 & $401^{\mathrm{a}}$ &, 161 &, 144 & 2,990 \\
\hline a. Predictors: (Constant), Gaya Kepemimpinan,Motivasi \\
\hline \multicolumn{3}{c}{ Sumber : data diolah }
\end{tabular}

Berdasarkan tabel di atas, diperoleh nilai R-square (koefisien determinasi) sebesar 0,161 maka dapat disimpulkan bahwa variabel Kepemimpinan (X1) dan Motivasi (X2) berpengaruh terhadap variabel kinerja karyawan (Y) sebesar 16,1\% sedangkan sisanya 83,9\% dipengaruhi oleh faktor lain.

\section{Uji Hipotesis (uji t)}

Pada pengujian ini juga menggunakan tingkat signifikansi $(\alpha)$ sebesar $5 \%$ (tingkat kesalahan $5 \%$ atau 0,05$)$ dan untuk mencari tabel menggunakan $\mathrm{df}=\mathrm{n}-\mathrm{k}-1$.

Tabel 10. Hasil Uji Analisis Uji t

\begin{tabular}{|c|c|c|c|c|c|}
\hline \multicolumn{6}{|c|}{ Coefficients $^{a}$} \\
\hline \multirow[b]{2}{*}{ Model } & \multicolumn{2}{|c|}{ Unstandardized Coefficients } & \multirow{2}{*}{$\frac{\text { Standardized Coefficients }}{\text { Beta }}$} & \multirow[b]{2}{*}{$t$} & \multirow[b]{2}{*}{ Sig. } \\
\hline & $B$ & Std. Error & & & \\
\hline 1 (Constant) & 14,683 & 6,214 & & 2,363 & ,020 \\
\hline Gaya Kepemimpinan & ,307 & 112 & ,263 & 2,735 & ,007 \\
\hline Motivasi & ,345 & , 137 & ,242 & 2,512 & 014 \\
\hline
\end{tabular}

a. Dependent Variable: Kinerja Karyawan

Sumber : data diolah

Berdasarkan tabel diatas, dapat disimpulkan sebagai berikut :Variabel Gaya Kepemimpinan (X1) berpengaruh secara positif dan signifikan terhardap kineja karyawan, hal ini terlihat dari nilai signifikan Gaya Kepemimpinan $(\mathrm{X} 1) \quad 0,007<0.05$ dan nilai $\mathrm{t}_{\text {hitung }}<\mathrm{t}_{\text {tabel }}(2,735>1.98447)$ maka Ho ditolak dan $\mathrm{H}_{1}$ 
diterima. Variabel Motivasi (X2) berpengaruh secara postif dan signifikan terhadap kinerja karyawan, hal ini terlihat dari nilai signifikan Motivasi.

\section{Uji Hipotesis (uji F)}

Pengujian ini dilakukan untuk mengetahui pengaruh semua variabel independen yang terdapat didalam model secara bersama-sama (simultan) terhadap variabel dependen. Uji f pada dasarnya menunjukan apakah semua variabel independen atau bebas yang dimasukan dalam model mempunyai pengaruh secara bersama - sama terhadap variabel dependen atau terikat. Pada pengujia ini juga menggunakan tingkat signifikan sebesar $5 \%$ atau 0,05 . Kriteria penerimaan dan penolakan hipotesis uji F adalah sebagai berikut:

Tabel 11. Hasil Uji Analisis Uji f

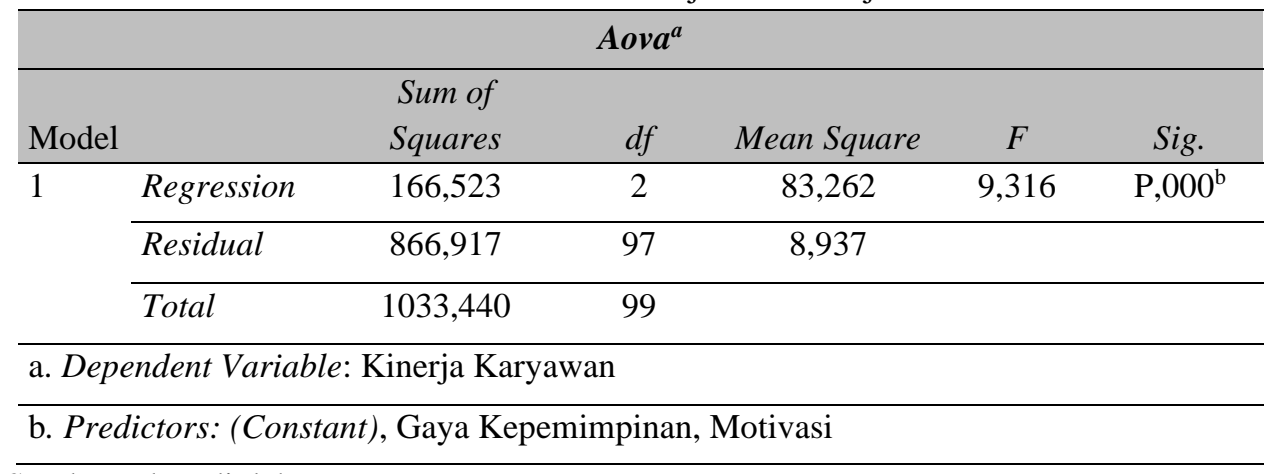

Sumber : data diolah

Berdasarkan tabel diatas, maka diperoleh nilai $F_{\text {hitung }}>F_{\text {tabel }}(9.136>3,09)$ dengan signifikan 0,000 $<0,05$ berdasarkan hal tersebut maka $\mathrm{H}_{\mathrm{o}}$ ditolak dan $\mathrm{H}_{\mathrm{a}}$ diterima dengan demikian secara simultan terdapat pengaruh positif dan signifikan antara Gaya Kepemimpinan dan Motivasi dan Kinerja Karyawan

\section{Pembahasan}

1. Pengaruh gaya kepemimpinan terhadap kinerja karyawan. Terdapat pengaruh atau hubungan positif (kuat) yang signifikan antara pengaruh Gaya Kepemimpinan terhadap kinerja karyawan yaitu 0,007 $<0.05$ dan nilai thitung <ttabel $(2,735>1.98447)$ maka Ho ditolak dan H1 diterima hal ini menunjukan bahwa kinerja karyawan PT. Kanmogroup di Jakarta (studi kasus divisi fashion kids justice) dipengaruhi oleh Gaya Kepemimpinan dengan kategori sangat kuat.

2. Pengaruh motivasi terhadap kinerja karyawan. Terdapat pengaruh atau hubungan positif (kuat) yang signifikan yaitu sebesar $0,014<0,05$ dan thitung < ttabel ttabel $(2,512>1.98447)$ maka H0 ditolak dan $\mathrm{H} 2$ diterima hal ini menunjukan bahwa kinerja karyawan PT. Kanmogroup di Jakarta (studi kasus divisi fashion kids justice) dipengaruhi oleh motivasi dengan kategori sangat kuat,dipengaruhi oleh faktor lain yang tidak diteliti dalam penelitian ini.

3. Hasil persamaan regresi berganda $Y=22,427+0,164 X 1+0,287 X 2$ berarti nilai constanta adalah 22,427 artinya jika tidak terjadi perubahan variable Gaya Kepemiminan dan Motivasi (nilai X1 dan X2) adalah 0 maka kinerja pada karyawan PT. Kanmogroup di Jakarta (studi kasus divisi fashion kids justice) sebesar 22,427 satuan. Tingkat signifikasi pengaruh antara Gaya Kepemimpinan dan Motivasi terhadap kinerja karyawan adalah signifikan. Hal ini dapat dilihat dari nilai Fhitung $>$ Ftabel $(9.136>3,09)$ dengan signifikan $0,000<0,05$ berdasarkan hal tersebut maka Ho ditolak dan Ha diterima.

\section{SIMPULAN}

Berdasarkan hasil penelitian di atas dapat ditarik kesimpulan: 
1. Terdapat pengaruh positif dan signifikan antara Gaya Kepemimpinan dan Kinerja karyawan kerja dimana diperoleh nilai dan nilai thitung > ttabel $(2,735>1.98447)$ dan signifikansi $(0,007<0.05)$

2. Terdapat pengaruh positif dan signifikan antara Motivasi dan Kinerja Pegawai kerja dimana diperoleh nilaithitung $>$ ttabel $(2,512>1.98447)$ dan signifikansi $(0,014>0,05)$

3. Terdapat pengaruh positif dan signifikan antara Gaya Kepemimpinan dan Motivasi terhadap Kinerja Karyawan dimana diperoleh nilai Fhitung $>$ Ftabel $(9.136>3,09)$ dengan signifikan $0,000<0,05$ berdasarkan hal tersebut maka Ho ditolak dan Ha diterima dengan demikian secara simultan.

\section{DAFTAR PUSTAKA}

Ardana, I. K., Mujiati, N. W., \& Utama, I. W. M. (2012). Manajemen sumber daya manusia. Yogyakarta: Graha Ilmu.

Asim, M. (2013). Impact of Motivation on Employee Performance with effect of training: Specific to Education Sector of Pakistan. International Journal of Scientific and Research Publications, 3(9), $1-9$

.Bangun, W. (2012). Manajemen Sumber Daya Manusia, Erlangga. Bandung.

Bellamy, A. J., Williams, P. D., \& Griffin, S. (2010). Understanding peacekeeping. Polity.

Budiartha, I. G. N., Bagia, I. W., Si, M., \& Suwendra, I. W. (2015). Pengaruh pelatihan dan motivasi kerja terhadap produktivitas kerja karyawan. Jurnal Manajemen Indonesia, 3(1).

Dessler, G. (2015). Manajemen Sumber Daya Manusia Edisi 14. Jakarta: Salemba Empat.

Ernawati , F \& Rusilowati, U. (2018). Pengaruh Gaya Kepemimpinan , Motivasi dan Kepuasan Kerja Terhadap Kinerja Karyawan (Pada Badan penelitian dan Pengembangan Kementrian Dalam Negri). Inovasi, Vol 5 hal 72-79

Ghozali, I. (2016). Aplikasi Analisis Multivariete IBM SPSS 23. Badan Penerbit Universitas Diponegoro, Semarang.

Hanafi, B. D., \& Yohana, C. (2017). Pengaruh Motivasi, dan Lingkungan Kerja, Terhadap Kinerja Karyawan, Dengan Kepuasan Kerja Sebagai Variabel Mediasi pada PT BNI Lifeinsurance. Jurnal Pendidikan Ekonomi Dan Bisnis (JPEB), 5(1), 73-89.

Hasibuan, M. S. P. (2013). Manajemen Personalia dan Sumber Daya Manusia. Jakarta: Bumi Aksara.

Hasibuan, M. S. P. (2017). Human Resources Management Revision Edition. Jakarta: Sinar Grafika Offset.

Hasibuan, M. S. P., \& Hasibuan, H. M. S. P. (2016). Manajemen sumber daya manusia. Bumi Aksara. Husain, B. A. (2018). Pengaruh Disiplin Kerja Terhadap Kinerja Karyawan Pada PT. Bima Bangun Sentana .Jurnal Semarak. Vol 2 No 3

Husain, B. A. (2019). Pengaruh Gaya Kepemimpinan Terhadap Kinerja Karyawan

(Pada PT. Bank Danamon Tbk Cabang Bintaro). Jurnal Disrupsi Bisnis: Jurnal Ilmiah Prodi Manajemen, Fakultas Ekonomi, Universitas Pamulang, 1(1).

J Winardi, S. E. (2015). Manajemen perilaku organisasi. Prenada Media.

Mangkunegara, A. A. A. P. (2016). Manajemen sumber daya manusia perusahaan. PT. Remaja Rosdakarya.

Mulyadi, M. (2018). Pengaruh Pelatihan Dan Motivasi Terhadap Kinerja Karyawan Pada PT. Permata Lestari. JENIUS (Jurnal Ilmiah Manajemen Sumber Daya Manusia), 2(1).

Onibala, N. R., Tewal, B., \& Sendow, G. M. (2017). Pengaruh Pendidikan, Pelatihan dan Pengembangan Karir Terhadap Kinerja Pegawai Pada Kantor Pelayanan Kekayaan Negara dan Lelang Manado. Jurnal EMBA: Jurnal Riset Ekonomi, Manajemen, Bisnis Dan Akuntansi, 5(3).

Pratama, G . D. (2020). Pengaruh Gaya Kepemimpinan Dan Motivasi Terhadap Kinerja Karyawan Pada PT. Garuda Karya Mandiri. Jurnal Ekonomi Efektif. Vol 2 : Hal 101- 142

Rivai, V. (2014). Manajemen Sumber Daya Manusia untuk Perusahaan, Edisi ke 6, PT. Raja Grafindo Persada, Depok, 16956. 
Rivai, V., \& Mulyadi, D. (2010). Kepemimpinan \& Perilaku Organisasi. Jakarta: Rajawali Pers.

Robbins, S. P., \& Judge, T. A. (2008). Perilaku organisasi (Organizational behavior). Jakarta: Salemba Empat.

Siagian, S. P. (2018). Teori motivasi dan aplikasinya. Rineka Cipta.

Sinambela, L. P. (2012). Performance Pegawai: Teori Pengukuran Dan Implikasi. Yogyakarta: Graha Ilmu.

Sinambela, L. P. (2016). Manajemen Sumber Daya Manusia, Membangun Tim Kerja yang Solid untuk Meningkatkan Kinerja.

Sinambela, L. P., \& Sinambela, S. (2019). Manajemen Kinerja. Jakarta: Rajawali Pers.

Sunarto, A. (2020). Pengaruh Gaya Kepemimpinan, Motivasi, Serta Disiplin Kerja Terhadap Kinerja Karyawan Study di PT Mitsui Leasing Capital Indonesia Abdul Muis- Jakarta Pusat). Kreatif. Vol 8 no 3

Sugiyono, P. D. (2013). Statistik untuk Penelitian. CV. Alvabeta Bandung.

Sugiyono, P. D. (2016). Metode Penelitian Kuantitatif, Kualitatif dan R\&D. Penerbit CV. Alfabeta: Bandung.

Sugiyono, P. D. (2017). Metode Penelitian Bisnis: Pendekatan Kuantitatif, Kualitatif, Kombinasi, dan R\&D. Penerbit CV. Alfabeta: Bandung.

Sulaiman, A. (2019). Pengaruh Gaya Kepemimpinan dan Motivasi Terhadap Kinerja Karyawan pada PT. Agra Energi Indonesia. Jurnal Ekonomi Efektif . Vol 1 : hal 77-8 